\section{I $\mathbf{B}$ A Institute of \\ YK Business Administration \\ तर Karachi \\ Leadership and Ideas for Tomorrow}

Article 1

Volume 9 Issue 2 July-December 2014

\title{
Front Matter of Volume 9 Number 2
}

Tufail A. Qureshi

Institute of Business Administration, Karachi

Follow this and additional works at: https://ir.iba.edu.pk/businessreview

Part of the Business Commons

(c) (i)

This work is licensed under a Creative Commons Attribution 4.0 International License.

\section{Recommended Citation}

Qureshi, T. A. (2014). Front Matter of Volume 9 Number 2. Business Review, 9(2), 1-10. Retrieved from https://doi.org/10.54784/1990-6587.1267

This article is brought to you by iRepository for open access under the Creative Commons Attribution 4.0 License and is available at https://ir.iba.edu.pk/businessreview/vol9/iss2/1. For more information, please contact irepository@iba.edu.pk. 
Volume 9 Number 2 July - December 2014

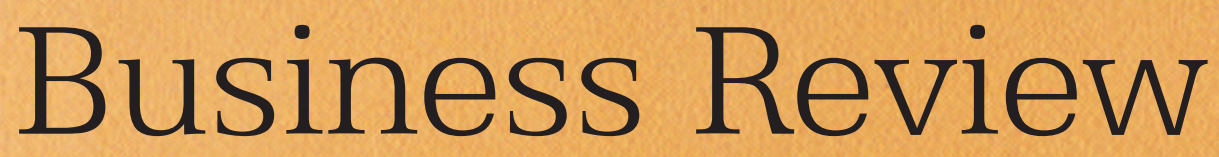

Leadership and Ideas for Tomorrow

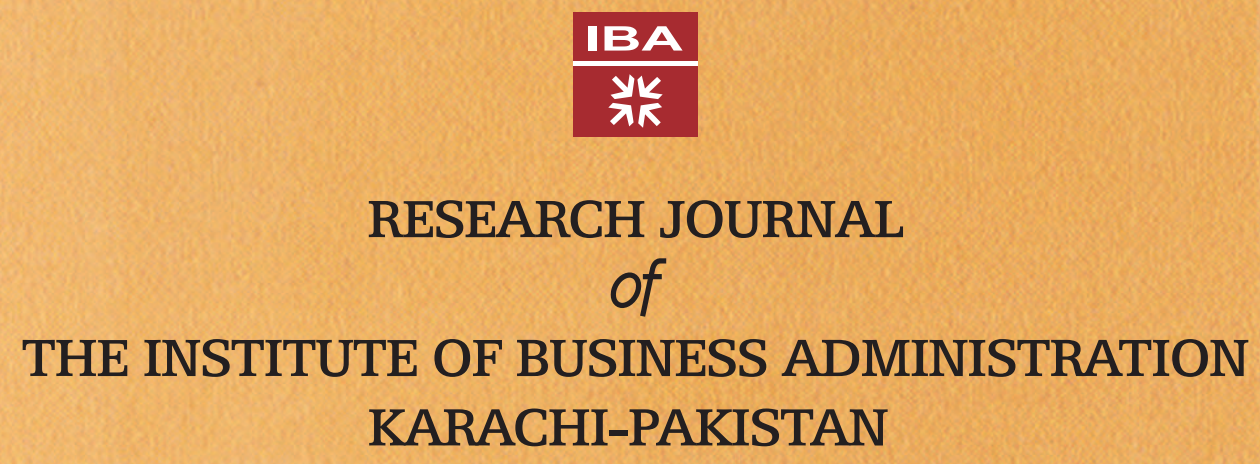


https://ir.iba.edu.pk/businessreview/vol9/iss2/1

DOI: https://doi.org/10.54784/1990-6587.1267

\section{IBA \\ 212 \\ 21}

\section{BUSINESS REVIEW}

Volume 9 Number 2

July - December 2014

\section{INTERNATIONAL EDITORIAL BOARD}

Ishrat HUSAIN

Chairman Board of Editors

Deepak KAPUR

Institute of Management Technology Ghaziabad, UP, India

Khurshid M. KIANI

Bang College of Business, Almaty Republic of Kazakhstan

S.W.S.B. DASANAYAKA

University of Moratuwa, Sri Lanka

Menno ADEN

Technische University, Dortmund Germany

Liu Jun YING

Jinanjin University, Jian Jin, China

Naved AHMED

Institute of Business Administration, Karachi, Pakistan

M. Aminul ISLAM

University Sain, Malaysia

Bettina ROBOTKA

Humbolt University, Berlin Germany

Akif HASSAN

Iqra University, Karachi-Pakistan

Khursheed OMER

University of Houston, Downtown Texas USA

Zeenat ISMAIL

Institute of Business Administration, Karachi-Pakistan

Huma BAQAI

Institute of Business Administration, Karachi, Pakistan
Tufail A. QURESHI

Editor

\author{
Arun Diwaker Nath BAJPAI \\ Rani Durgavati University, Jabalpur, (MP) India \\ Talat A. WAZARAT \\ Institute of Business Administration Karachi-Pakistan \\ Shamas-ur-Rehman TOOR \\ University of New South Wales, Australia \\ Khadija Malik BARI \\ Institute of Business Administration Karachi-Pakistan \\ Ahmed Audu MAIYAKI \\ Bayero University, Kano Nigeria \\ Agung NUGROHO \\ Atma Jaya Cotholic University, Jakarta, Indonesia \\ Faisal Manzoor ARAIN \\ Southern Alberta Institute of Technology Canada \\ Low Sui PHENG \\ National University of Singapore \\ Badar Alam IQBAL \\ Aligarh Muslim University Aligarh,(UP) India \\ Abdul RASHID \\ Intrnational Islamic University, Islamabad-Pakistan \\ Mirza Sardar HUSSAIN \\ Institute of Business Administration, Karachi-Pakistan \\ Nadir Ali KOLACHI \\ Sky Line University, U.A.E
}

Business Review is a peer reviewed bi-annual research journal of the Institute of Business Administration (IBA) Karachi. It is recognized by the

Higher Education Commission (HEC) of Pakistan and is internationally abstracted/ indexed in the Journal of Economic Literature (JEL) and EBSCO database. 


\title{
BUSINESS REVIEW
}

\author{
IBA \\ 牙K
}

RESEARCH JOURNAL

of

THE INSTITUTE OF BUSINESS ADMINISTRATION

KARACHI - PAKISTAN 


\section{CONTENTS}

Editorial Perspective $\quad 1$

\section{ARTICLES}

Track II as a Method to Break Barriers: Pakistan-India Relations since 1980

Talat A. Wizarat

Wealth Effect of Mergers \& Acquisitions in Emerging Market:

Sana Tauseef, Mohammed Nishat

Incorporating Emotions as Antecedents and Mediators in Theory

of Reasoned Action (TRA) Model

Mobin-ul-Haque

Corporate Governance and Cash Holdings in Listed Non-Financial Firms in Pakistan 48 Alina Masood, Attaullah Shah

Components of The Brand Equity of Internet Service Providers (ISPs) In Paksitan

\section{Kashif Farhat}

Strategic Management Research: the Missing Linchpin in Developing

Irfan Saleem

The Puzzle of Mainstream and Deviant Globalization

Grounded Ontology - A proposed methodology for emergent ontology engineering Syed Irfan Nabi

Perceived Service Quality Of Electricity Supply In Nigeria: A Survey Of

Manufacturers In Kakuri Industrial Estate, Kaduna

Abdulsalam Dauda, Mohammed Abubakar Mawoli, Abdullahi Yusuf Babandako

\section{CASE STUDY}

Impact of Effectuation Based Interventions on The Intentions to Start a Business

Muhammad Shahid Qureshi, Fawad Mahdi

Growth of Business Schools on Social Media:

A Comparative Analysis with focus on IBA Karachi

Erum Hafeez Aslam

Defense Expenditures and Economic Growth in Pakistan and India:

An Augmented Feder-type model

Muhammad Ramzan Sheikh

\section{NEW \& VIEWS}

NazlKramullah. Ganga Jumuni:

Silver and Gold, A Forgotten Culture. Bengal Publications, 2013. 


\section{Editorial Perspective}

\section{The Case for Corporate Man: Who is he?}

If you see a man walking down the corridor and you do not know him, you ask: Who is he?

If you see a strange object sitting in the corner of the corridor, which you have never seen before, you ask: What is that?

There is a familiar difference between the two questions and it makes all the difference in the world. A man is a who and not a what. He is a subject and not a thing. He has a face and he can ask: Who am I?

So, who is he; the Corporate Man?

We do not know. Or, do we?

We are familiar, as much as we are, with as many faces of man as we have met on the vast landscape of human typology. Each one of them represents a worldview and carries a heavy burden of the present tense meaning of life, the realities of the modern world and the future he has so unwisely made uncertain for himself.

We have committed sins living in denial and bad faith and we have missed our watershed moments. Ideas are our scarcity but we are not short on dreams and hopes. We do not know how and when to invest ourselves in our future. But, our yearning for the miraculous is unbounded. In a place like Corporate Pakistan, it is so easy to live with diminishing resolve not to desire the undesirable. But so we live- obstinate, obdurate, and stubborn. Happy and contented with what is, unwilling and hesitant to imagine what can be and therefore ought to be. How quick we are to default on the promise of yet to be; how dithering in search of the world to be! Why?

Let us ask the Corporate Man: some haphazard questions: Who has extricated the human face from the narrative of your context and discourse? From your being-in-the-world? Who has omitted the human and moral order from the many faces of corporate reality? Who has curbed your creative restlessness killing softly your hope for what the future can be? Your creative will to will the truth, your creative imagination; to generate ideas for tomorrow, your inclination to assume the role of leadership? Your passion to understand the power that lies buried deep down in your being able to be? Have you not lost so much? How much more can you afford to lose? Think. Is this the present you were longing for yesterday, prolonging your agony for the future that will be yours and to which you will belong tomorrow? Are you still longing for what could have been? Nostalgic for the world to be?

Let us say to him this, and much more than this. Don't be afraid to love truth more than the thing you love. Dare to think dangerously. Dare to be wise. Speak so that we may see you. Let us see who you are. Remember the saintly Abraham Lincoln and his words of wisdom "whoever you are, be a good one." These are challenging words. They cover the vast spectrum of ethico-moral and existential landscape of our quest for being. Show us your face. Develop your voice. Sing your life in your song. Think of us in your thoughts. Come out of your hiding. Announce yourself. You have nothing to lose but your anonymity. You have but one obligation; to become who you are capable of becoming.

A typical Corporate Man can be described in several ways. The thought here is not about profiling him as one of them. The thought, not a very comforting and easy one, is to 
demonstrate to ourselves an understanding of what it means and what it takes to make the case for him. To name some of the thematic profiles of man on whom so much wisdom has been invested and a great many ideas have been spent to examine the meaning of his being a human being, an educated human being, an ethical and moral human being, not from a single, an exclusive and one dimensional view but from several perspectives. Each one of these ways of his being gives rise to mighty questions which are bound to lead to intense disquietude, involved conversations, huge discourses pertaining to critical narratives on the agonizing reflections on decision making and the place of value in doing what he ought to be doing, as best as he can.

Many learned men, thinkers and research scholars, have spent so much of themselves to deepen and enlarge our understanding of man, his thoughts and ideas, hopes and fears, frailties and valor, creative rage and the will to truth; each as an extension of his being a human being. Each one of these profiles, alone in its own way, and in coalition, is a summing up conclusion about human metaphor. It is part of a process, as it has unfolded itself, not just like that, but as a manifestation of socio-cultural, political and economic development and, above all, the principle of movement and change towards the 'yet to be'? In retrospect, it cannot be stripped of the history of its recent past.

Each society projects its own image of man into its arts and literature, philosophy and culture, its worldview and ethico-moral dispensations eschewing the burden of petrifying world, wanting to escape into a world to be, sadly disappointed and unhappy with the world as it is eager to live in a world as it ought to be.

We live in times when "the world" as an amorphous and vacuous concept has ceased to exist. In times like ours, only the worlds exist; materialistic or idealistic, just or cruel, human or brutish, yours and mine, ours and theirs. Corporate world is one of those many worlds. It is the world of Corporate Man. Modern man has many faces, wearing well-crafted masks. Corporate man is an anonymous incognito man without a face, without a name, happy and secure in his knowledge that nothing is permanent, nothing abides, nothing is ever the same. An anecdote from Heraclitus, the ancient Greek philosopher.

But, does the corporate man understand the power of corporate reality and his own creative will to shape his future by constructing and reconstructing it according to the vision and his heart's desire, by generating new ideas and, in his creative resolve, transcending the petrifying exclusiveness of thus it is and it cannot be other than what it is? Is he the man who is willing to grow older gracefully to test the limits of what he is capable of doing and therefore by doing it, to become what he ought to be. In life a great deal, if not everything, depends upon his creative vision.

"What do we mean by vision? Essentially, vision is mental Journey from the known to the unknown, creating the future from a montage of current facts, hopes, dreams, dangers, and opportunities. . . . Such a journey can dictate the success of business; and just as nations must adapt their original visions to changing conditions, so must corporate leaders mould their visions to keep pace with a rapidly evolving world."

Hickman, C.R. and Silva, M.A., Creating Excellence, p.151 
So, the Corporate Man is a journeying self. He is a creature whose journey, towards self-realization and self-fulfillment, is fraught with the possibilities of his being and not being. That is his existential situation. He cannot be without being; and the logic of it is that being without being is not being at all. That is his human predicament. There is a moral and ethical side attached to his being a human being but it is not confined to ethics and morality. There is also an epistemological side to it and, equally importantly, his ontogenetic evolution. That means that he cannot be without becoming what he knows. If he knows what the truth is, he must then become truthful. Otherwise he lives in denial and bad faith. In life our greatest problem is to give expression to feelings and moods, value judgments, affirmations and negations, which we all have to face and live with in our lifetime.

Moreover, man, whoever he may be, is an autobiographical consciousness. He is who he is because he decided and chose to be this rather than that. It is not a small matter; although it looks apparently so simple to make a choice, to say 'yes' or 'no', 'to be' or 'not to be'. In fact it is not only our authenticity and veracity that is at stake, more so, it is what we alone can do as best as we can: to be and to become what we are capable of becoming. All else is innocuous and naïve if our fate and destiny does not flow from our choices and decisions. We cannot relegate this task to anyone nor can we hold someone responsible for our misfortunes and suffering. Whatever happens to us, we make ourselves a candidate for it. Let us not forget that not to choose for ourselves is in itself a choice and not to decide for or against is itself a decision. Our foes are many and most of them within. Our friends are few and often hard to recognize.

In the corporate world, except for solitary voices, there is no alternative discourse to counter the narrative that the corporate system is flawed and tardy. The foundations of corporate culture have been severely undermined by insistence of the corporate executive upon mutually exclusive categories, the either/or dichotomies, artificially created conflict; e.g., between ethics and economics, a laise faire attitude towards profit and material aggrandizement, blatant and exploitative disregard for corporate social responsibility and ethico-moral imperatives. Thus it is and, thanks to our acquiescence to the glorious status quo, so it must remain, as a fait accompli.

Corporate Pakistan is a unique and peculiar phenomenon because the very thought of it arouses emotions of pity and contempt. But beside the painful assortment of the features typifying the way it has become, mercifully there are many a redeeming possibilities which, if they are not consigned to risk averse indifference and apathy as wasted and lost opportunities, we can still hope to make some amendments for the collateral damage we have already done to our socio-cultural fabric.

We are living in "interesting times." These are the times when honest and sincere people dare to think creatively - reimagining, re-constructing and reviewing their lives and their worldview. These are the times when honorable men ask painful questions and fear not the painful answers. In times such as these, men of good faith and creative will decide how to live and when to die. They are the men of vision, in tune with the markings of times. During these times men of vision and destiny do not weep or cry, nor do they wax indignance. They do not slumber. But, while their companions sleep they are toiling upward in the night; true to earth and the realities on the ground. 
They hate to stay just the same; they are not afraid to change. All great minds and all great societies change. They glorify the principle of becoming. They want to be. Transcending the propensity for acquiescence they celebrate the principle of movement in life. We are on our way towards the yet to be and it is a long way from here to the world to be. Our hearts are filled with hope and we can hear the "distant drums".

How long shall we wait for iconoclasm? Have we not waited long enough for radical thinkers, invincible and unconquerable minds, especially in the field of teaching and leadership to enhance the desired level of excellence to facilitate the demolition of idolatrous beliefs and ideas lodged in our hearts and minds?

In the Qur'anic parlance, there is a sickness in man's heart which does not let him be. It is due to his subservience to the unusable past that has lost its creative and dynamic relevance for the present and also his slavish attachment to the unexamined beliefs and ideas whose knowledge claims are unquestioningly accepted and taken for granted. These are the idols we must ruthlessly demolish, destroy and shatter into bits, to be free -free from "fear and trembling" and inner doubt whether to be free or not to be free. Both, societies and individuals, function on the same principle when they are confronted with a choice to provide perspective to their narrative of the world as it is; in search of the world as it ought to be. It is the creative rage, the will to truth and the vision of the world to be. Is the corporate man brave enough to demolish the Baconian

- Idols of the Tribe. The dogmas and the erroneous assumptions which give legitimacy to the unexamined norms and taken for granted traditional beliefs? Idols, the taboos and totems?

- Idols of the Cave. The flawed narratives that make man worship petrifying traditions, customs, loves and hates, hopes and fears, prejudices and biases?

- Idols of Market Place. The symbols, metaphors, allegories and the themes on which variations are constructed to be played out on the stage of market governed economy and corporate values?

- Idols of the Theatre.Eulogizing ideologies, attitudes, mannerism, axioms, tastes and new but vulgar and arrogant patterns of thought and narratives?

These idols thrive and feed upon our heart's desire; they are lodged in the inwardness of our being. That is where they must be destroyed to liberate our hearts and minds from venomous hatred and greed, dishonesty and deceit, lust for power and authority, fear of death, impulse rather than intuition, reaction rather than reason.

Abandoning such an essential component of teaching and learning in our institutions of higher education we have abdicated our responsibility to the harmonious intellectual, moral and socio-cultural development of our students. It is tantamount to pedagogical sin and we who have made teaching our calling are guilty of such crimes. Year after year, as the events unfold on the landscape of Corporate Pakistan, we find it even more difficult to forget our past and, if we are honest to God, unwilling to forgive ourselves. Such a mindset is the breeding place of pity and contempt, grief and sorrow. Our collective memory works only in spurts. We are incapable of making promises to ourselves, reneging on those we had committed ourselves to keep. We are cloistered people, undecided about honor without honesty and glory without moral grace. Apart from fear and cowardice and also greed and lust for pleasure - no other emotions keep our thinking - feeling -willing unity harmoniously 
integrated. Otherwise, we go to pieces, shattered into bits, scattered all over the domain of vulnerability. Living in such a context, it is not an easy task to make The Case for Corporate Man or to make and remake him to construct and reconstruct the Corporate World.

In the following sparsely stated ideas, together and in juxtaposition, we have designed a multifaceted sphinx to make The Case for Corporate Man. It is a naïve analogy with a striking difference, indeed. But naïve only if we adhere to a one dimensional description, as opposed to a broad interdisciplinary profile of the corporate executive. So, the analogy serves the purpose of saving the corporate man from becoming the dupe of an insulated description that is based on disregard for the unity in diversity of inter-disciplinary narrative with the focus on common denominators, in different contexts and from several perspectives.

Each man lives more than one life but each man does not die; not even a little death. In the Corporate World, as in the Beaurocratic World, our functionary lives under the surge of glass managery, ready to wear the well-crafted mask, to suit the impulse, betraying his real identity in the unguarded moments or under the spur of fleeting moment, forgetful of wearing the wrong mask. How silently and skillfully he then melts away into someone reincarnate.

In the following nuanced profiles of modern man, which cut across the vast spectrum of the corporate landscape, let us see if we can recognize the lurking shadow of the Corporate Man. Besides, we offer a review of quotations from random selection of books, not the suggested or recommended course books, to cover a small number of thematic narratives.

\section{Irrational Man}

"To be rational is not the same as to be reasonable. In my time I have heard the most hair-raising and crazy things from very rational men . . . Nowadays, we accept in our public and political life the most humanly unreasonable behavior, provided it wears a rational mask and speak in officalese, which is the rhetoric of rationality itself."

William Barrett, p.270

\section{Technological Man}

"Modern man is far from slaying the beast within; why assume that the man of the future will be a completely new creature?"

Victor C. Ferkiss, p.25

\section{One Dimensional Man}

"The transcendent project must be in accordance with the real possibilities open at the attained level of the material and intellectual culture."

Herbert Marcuse, p.22

\section{Man Alone}

"The past few hundred years have seen major scientific and technological revolutions in half the world, while the other half still plows the earth with dull sticks. Unparalleled economic growth has occurred side by side with the profoundest human misery; and 
struggles for freedom and enlightenment side by side with continuing social injustice."

Eric and Mary Josephson, Introduction

\section{Between Man and Man}

"Education worthy of the name is essentially education of character. For the genuine educator does not merely consider individual functions of his pupil, as one intending to teach him only to know or be capable of certain definite things; but his concern is always the person as a whole, both in the actuality in which he lives before you and in his possibilities what he can become."

Martin Buber, p.104

\section{Know Thyself}

"I am the center of my world and consequently I imply the world. On the other hand, my world implies me, as the center of it."

Bernardino Varisco, P.38

\section{Man, The Unknown}

"Man, as known to the specialists, is far from being the concrete man, the real man. He is nothing but a schema, consisting of other schemata built up by the techniques of each science. . . . But he is also the poet, the hero, and the saint. . . . our conceptions of him are imbued with metaphysics. They are founded on so many and such imprecise data that the temptation is great to choose among them those which please us. Therefore, our idea of man varies according to our feelings and our belief. A materialist and a spiritualist accept the same definition of a crystal of sodium chloride. But they do not agree with one another upon that of the human being."

Alexis Carrel, p.3

\section{An Essay on Man}

"It follows from the very nature and character of ethical thought that it can never condescend to accept "the given". The ethical world is never given; it is forever in the making. "To live in the ideal world", said Goethe, "is to treat the impossible as if it were possible."

Ernst Cassirer, p.61

\section{Man's Search for Himself}

"The hallmark of courage in our age of conformity is the capacity to stand on one's own convictions - not obstinately or defiantly (these are expressions of defensiveness not courage) nor as a gesture of retaliation, but simply those does one believe. It is as though one were saying through one's actions, "This is I, my being". Courage is the affirmative choice, not a choice because I can do no other; for if one can do no other, what courage is involved?"

Rollo May, pp201-202 


\section{The Folklore of Management}

"The businessman needs the skills of the politician, and the politician needs the skills of businessman. Neither can afford to call the other bad names. It is not true that all politicians lack principle, and not true that the businessman responds only to self-interest. Dishonesty and selfishness are human defects that are attributes of a particular human being, not symbols of calling."

Clarance B. Randall, p.131

\section{Good to Great}

"We were surprised, shocked really to discover the type of leadership required for turning a good company into a great one. Compared to high-profile leaders with big personalities who make headlines and become celebrities, the good-to-great leaders seem to have come from Mars. Self-effacing, quiet, reserved, even shy - these leaders are paradoxical blend of personal humility and professional will. They are more like Lincoln and Socrates than Patton or Ceaser."

Jim Collins, p.12-13

\section{World According to Drucker}

"Drucker discusses economic life in terms of values, integrity, character, knowledge, vision, responsibility, self-control, teamwork, community, competence, social responsibility, the quality of life, self-fulfillment, leadership, duty, purpose, dignity, meaning- but rarely money. He defends profit, but as if it were broccoli; a distasteful obligation of managers who would rather be reading Kierkegaard."

Jack Beatty, P.176

The 7 Habits of Highly Effective People

We focus "on what could be called the Character Ethics as the foundation of success - things like integrity, humility, fidelity, temperance, courage, justice, patience, industry, simplicity, modesty and the Golden Rule . . . is, basically, the story of man's effort to integrate certain principles and habits deep within his nature.

The Character Ethic taught that there are basic principles of effective living, and that people can only experience true success and enduring happiness as they learn and integrate these principles into their basic character.

But the basic view of success shifted from the Character Ethic to what we might call the Personality Ethic. Success became more a function of personality, of public image, of attitudes and behaviors, skills and techniques that lubricate the process of human interaction."

Covey, Stephan R. pp18-19 
Violent Man

In the phenomenology of the world of violent men, Toch offers an interesting insight into the typology of violent man. His observations on the 'Violence in Perspective' begin with these words:

"Few categories of conduct evoke more concern than the subject of this book. Social critics equate violence with decay, statesman deplore its prevalence, and unprecedented resources are marshaled to combat it ... We are told that violence lurks within us, that we dole on it, wallow on it, and that we must exert enormous effort to suppress it."

Hans Toch, P.1

\section{The Humanization of Man}

In discussing "Our Present Culture and Its Ills," Ryan observes, and his observations spread over the vast landscape of corporate society.

"In any systematic attempt to humanize our society, it is obvious we must begin by taking four diagnostic steps. We must observe the difference between what we are and what we might be. We must examine the philosophy that is largely responsible for bringing us to our present state, and then that which should guide us in achieving a better state. And, finally the method which the implementation of this latter philosophy dictates. . . .

Beyond this, a truly humane society would also be one in which the members would be relatively happy because normally skillful in all their noneconomic activities as well. Thus, they would be trained to move easily and gracefully, without apparent effort. They would speak resonantly and clearly. They would sing freely, melodiously, spontaneously. They would dance unselfconsciously, without any forced bacchanalian gaiety. They would write a hand that was pleasantly calligraphic. The casual maps or diagrams they had to sketch, in explaining something to a friend, would please both mind and eye. They would design and choose clothing which, while comfortably functional, would be expressively personal. They would build homes and shops that both in structure and appearance would foster a warmly human way of life. They would serve nutritious meals which would also be symphonies of tastes. They would converse or compose letters pointedly, wittily or compassionately, as occasion demanded. In these and the many other activities of daily living, therefore, they would continuously experience the delights both of performing things well themselves, and of enjoying the similarly skillful performances of others."

Rayan, John Julian, pp3-7

To understand the context to which we belong, to understand the world in which we live, we need to understand the world we share with others, the lived-world that belong to us and to which we belong. To know where we are going, it is necessary to remember where we 
are coming from. To reach the goal we are seeking, we need to know the right path and also the right direction. It is not uncommon for the seekers, the travellers, the journeying selves, to be on the right path and yet moving in the wrong direction. Such is the futility of human endeavors and the tragedy of human societies. They never arrive anywhere near the goal they are seeking.

To inherit the future they desire for themselves, they do not always desire the desirable, nor do they always preserve what is worthy of preservation. To live in a "brave new world", the world to be, they lack creative vision and imagination, above all the will to truth. They never understand that in life the only way to go is the way forward and onward, towards the yet to be. Life teaches us that to live means to outlive, to grow means to outgrow and to be means to become. Living is a creative venture and existential discontent. It is an act of surpassing the world that has grown old and weary of new ideas and new thoughts, new possibilities, new ways of seeing and new ways of being in the world.

The habit of critical thinking, historical criticism, creative judgment, ethico-moral reevaluations, all of which are quintessential of liberal and progressive education are also the essential features of the world that is yet to be. The concept of a constantly changing and dynamic reality of the world demands a pedagogical strategy to evolve new methodologies to reflect inclusion rather than exclusion of new ideas and concept, struggling for their relevance in the Corporate Worldview.

Abandoning such an essential component of teaching and learning in our institutions of higher education we have abdicated our responsibility to the harmonious intellectual, moral and socio-cultural development of our students. It is tantamount to pedagogical sin and we who have made teaching our calling are guilty of such crimes. Year after year, as the events unfold on the landscape of Corporate Pakistan, we find it even more difficult to forget our past and, if we are honest to God, unwilling to forgive ourselves. Such a mindset is the breeding place of pity and contempt, grief and sorrow. Our collective memory works only in spurts. We are incapable of making promises to ourselves, reneging on those we had committed ourselves to keep. We are cloistered people, undecided about honor without honesty and glory without moral grace. Apart from fear and cowardice and also greed and lust for pleasure - no other emotions keep our thinking - feeling -willing unity harmoniously integrated. Otherwise, we go to pieces, shattered into bits, scattered all over the domain of vulnerability. Living in such a context, it is not an easy task to make The Case for Corporate Man or to make and remake him to construct and reconstruct the Corporate World.

When we cease to imagine more than the petrifying "thus it is and it cannot be other than what it is," our creative will wills nothing. We sacrifice hope at the altar of necessity and condemn ourselves to a fixed immutable reality and a world bereft of creative possibility.But, to creatively reimagine the world, corporate man has to strive for a dialectical synthesis of thus it is and thus it ought to be, resulting in the emergence of the world to be.

This is an arduous task and a neglected theme in our institutions of higher education. As teachers, if we wish to be true to our calling to make the case for Corporate Man, we must strive for a synthesis of liberal arts and humanities, ethics and economics, philosophy and religion. It may sound a superfluous idea. But the lure of specialization and our fascination for departmental training should make us weary of the kind of skill and training which has indeed the economic and pragmatic value and is also a sign of the time. But the assumed boundaries and demarcations between various disciplines are artificially drawn; they do not 
serve us well in our complex, interdependent and rapidly changing world, including the Corporate World.

Being trained into a given field of academic discipline and specialization, with no emphasis on wisdom and virtue, ethical behavior and moral character should not deserve the name of education. Such education and training too means little and fails to do much as an educational ethos and a world-view unless it also teaches us how to live a good life and be a good man. An educated man, beside all else, is essentially a good man. Good life and ethical behavior is not an act but, as Aristotle believed, it is the result of cultivating good moral habits.

Reality, including corporate reality, has many faces; beautiful and ugly, alluring and repulsive. This is another anecdote from the early Greeks but relevant still. Therefore, Protagoras believed, man is the measure of all things. But who is this mysterious man whose judgments and evaluations are the measure of truth and reality? You, me or the Corporate Man?

To be continued....

Tufail A. Qureshi

"Social life is beset with disparities between others' perceptions of us and our reality. We are accused of stupidity when we are being cautious. Our shyness is taken for arrogance and our desire to please for sycophancy. We struggle to clear up a misunderstanding, but our throat goes dry and the words found are not the ones meant. Bitter enemies are appointed to positions of power over us, and denounce us to others. In the hatred unfairly directed towards and innocent philosopher we recognize an echo of the hurt we ourselves encounter at the hands of those who are either unable or unwilling to do us justice."

Alian de Botton, The Consolations of Philosophy, p.40-41 